\title{
Exploring the European Union Renewable Energy Directive and its Implications for Indonesia's Palm Oil Industry ${ }^{1}$
}

\author{
Bondan Widyatmoko \\ Research Center for Regional Resources \\ Indonesian Institute of Sciences
}

\begin{abstract}
The Renewable Energy Directive (RED) is a vehicle for environmental NGOs concerned about biodiversity destruction in Indonesia, for European biodiesel producers to admit new competitors, and for European Union (EU) interests to build a secure and sustainable economy for their region. In other words, it is a manifestation of the different interests of many agencies that share grace and favour over palm oil development in the EU. By observing the RED as the vehicle and the EU system of governance as its course, this paper records the interactions between those agencies in shaping the policy. The observations allow for agencies contributions to the images of palm oil. It depicts that biodiversity destruction is the basis for the sustainability criteria in the RED but it was not the only cause of the slowing down in the pace of the Indonesian palm oil market penetration in the region. To some extent, the RED is considered a trade barrier for Indonesian palm oil. However, the RED is an incentive to strengthen the image of the palm oil industry in a more constructive way and ensure the longevity of the industry.
\end{abstract}

Keyword: Renewable Energy Directive (RED); Palm oil; European Union; Indonesia

\section{INTRODUCTION}

The Renewable Energy Directive (RED), which was implemented by the European Union (EU) in June 2009, directly and indirectly, has pushed for active programs by the Indonesian government and palm oil producers to improve the image of the palm oil industry. ${ }^{2}$ Initially, Indonesia was confident that the RED was not consistent with World Trade Organization (WTO) regulations. ${ }^{3}$ This position was supported by statistical facts that the European countries were placed after India and China as the main destination for Indonesia's palm oil exports. From a legal and economic point of view, Indonesia did not see the RED as an obstacle for its palm oil industry. However, as a political manifestation of 28 countries in the EU, the RED could be phenomenon of 'rashomon mirror', where many interpretations have led to different conclusions and actions.

The last statement does not mean to disparage the economic, political and security harmonisation efforts in the EU, but a successful implementation of the RED to regulate commodities based on the production process had shed light on other similar policies in the region.

1 This paper was presented at the Palm Oil Study Club Kyoto Seminar on 1 November 2014 at the Centre for Southeast Asian Studies (CSEAS), Kyoto, Japan.

2 There are at least two government initiatives that confirm Indonesia as the world's biggest palm oil producer. Those are the Indonesian Sustainable Palm Oil (ISPO) and palm oil sustainable campaigns through international events. The most recent event was the Indonesia palm oil pledge at 2014 United Nations Climate Summit.

3 The main reason, according Rosdiana Suharto, Chairman of Indonesian Sustainable Palm Oil (ISPO), that Indonesia need not worry about the effects of RED by the EU, is the absence of environmental standards for palm oil in WTO regulations (Sawit Indonesia, 2014). This statement implied that RED is violating the international trade mechanism upheld by the WTO member countries. 
By the end of 2014, European legislation, the EU regulation 1169/2011, is to be implemented. This legislation obliges food producers to indicate which vegetable oils are used in their products and to put this information on the labelling. Though this legislation is not specifically a regulation for palm oil, it has, unfortunately, induced 'creativity' from European Union member states (EU-MS) and other organisations in interpreting the legislation. Belgium and France, for example, through their national parliaments, agreed to legislate for a palm oil tax for health reasons. ${ }^{4}$ In addition, several food producers, influenced by a movement named 'sans huile de palms', rewrote their food labels together with environmental and health advocacy to reduce palm oil consumption.

The food labelling regulations that were applied after the RED came into force appear to be to regulate the production process of a particular commodity. Under the pretext of environmental and public health, these policies try to influence palm oil producers to use sustainable production practices and to protect the health of EU-MS citizens. These policies might fail to violate the WTOGATT agreements. ${ }^{5}$ However, this paper is not to discuss the possibility that the policies are de facto mechanisms to protect domestic commodities that compete in the market with palm oil. It rather puts emphasis on describing the EU political circumstances that allow such policies. By observing the RED as a vehicle for change and the EU system of governance as its course, this paper describes the interactions between state and non-state actors in shaping policy. The first part of the paper explains the RED and its historical development and is followed by a description of the role non-government organisations play in the EU and in third nation countries (in this case Indonesia) in shaping the RED. The last part of the paper outlines some implications of further policy pressure on palm oil production and exports as EU regional integration increases, and for Indonesian responses as the biggest palm oil producer.

\section{RED FORMATION AND EU INTERESTS IN ENERGY SECURITY, GROWTH AND THE ENVIRONMENT}

Although implementation of the RED started in 2009, its creation cannot be separated from the cumulative policy efforts to utilise renewable energy resources in the European Union (EU). The EU Commission's White Paper in 1993 on growth, competitiveness and employment, acknowledged the positive relation between the environment and economic prosperity. ${ }^{6}$ This White Paper was followed by a Green Paper on community strategies for renewable sources of energy in 1996, in which were drafted three objectives. The first was to double, by 2010, the use of renewable energy resources (or close to 12 per cent) for EU consumption. The second was to strengthen energy policy cooperation and to urge each EC (European Commission) member country to reinforce policies for developing renewable energy. The last was to pursue effective assessment and monitoring to achieve those objectives. $^{7}$ One year later, the Green Paper engendered a White Paper that gave shape to a strategy and action plan for renewable energy sources. ${ }^{8}$ The White Paper listed several likely regional sources

4 According to Mr Havas Ogrosuseno, the Indonesian Ambassador for Belgium, the regulation has caused a financial burden for Indonesia. (Interview, 2014).

5 Looking back at the shrimp and tuna case, the RED and taxing policies of the EU-MS, these probably violate articles I, III, and XI of GATT, even though it is allowed to utilise the exemption under the article XX.

6 Commission of the European Community. (1993). Growth, competitiveness, employment. The challenges and ways forward into the 21st centuries. White Paper. [online] http://aei.pitt.edu/1139/1/growth_wp_COM_93_700_Parts_A_B.pdf .

7 Commission of the European Community. (1996). Energy for the future: renewable sources of energy. Green Paper for community strategy. [online] http://aei.pitt.edu/1280/1/renewalbe_energy_gp_COM_96_576.pdf .

8 Commission for the European Community. (1997). Energy for the future: renewable sources of energy. White Paper for a community and strategy and action plan. [online] http://europa.eu/documents/comm/white_papers/pdf/com97_599_en.pdf. 
for renewable energy to achieve the target. Those are biomass, wind, solar-thermal, photovoltaic, geothermal and heat pumps. These energy sources are projected to contribute to electricity and heat production as well as the transport sector.

Following the White Paper, two directives were promulgated to implement the strategy and plan. In 2001, the EU enacted directive 2001/77/EC on the promotion of renewable energy resources for electricity generation. This directive not only set a goal for electricity produced from renewable sources to increase to 21 per cent by 2010, but it also urged the EU Commission to set binding or mandatory conditions to the implementation to ensure all EU-MS meet the target. ${ }^{9}$ Coming after these directives, the EU implemented directive 2003/30/EC to promote renewable fuels for the transport sector. It set intermediate and final goals for biofuels and other renewable fuels available in the market; respectively, 2 per cent in 2005 and 5.75 per cent by the end of $2010 .{ }^{10}$ Unlike the previous directive, it allows moral obligations of EU-MS in meeting their objectives.

Furthermore, those directives were a consequence of the spirit of reducing $\mathrm{CO}_{2}$ emissions as part of the commitment of the Community to the Kyoto Protocol. In other words, pursuing energy security and competitiveness should not decrease the importance of environmental sustainability. In this context, both directives show different approaches to keep the value of environmental sustainability in place. Directive 2001/77/EC, in article 5, requires EU-MS to guarantee the origin of electricity that is produced from renewable resources. The guarantee should cover the sources, dates and place of production as well as capacity. To avoid disputes about internal trade in electricity, the European Parliament (EP) and European Council want the Commission to adopt common rules for all EU-MS.

This measurement is more technical compared to directive 2003/30/EC, which only required EU-MS to consider the climate and environmental balance in meeting the objective (article 3). However, in the following article (article 4) the Commission asked the EU-MS to give a report covering cost effectiveness in the promotion of biofuels, including the accompanying economic and environmental effects.

The difference in the legal emphasis for both directives was shown in the results. Although directive 2001/77/EC reached its goal by 2010 , other directives did not. ${ }^{11,12}$ In 2005 , a clear direction had been given by the Commission to meet the goals of directive 2003/30/EC through the Biomass Action Plan and the EU Strategy for Biofuels, but a binding mechanism was necessary to be inserted in the policy. ${ }^{13,14}$ In addition, the biofuel progress report shows that a combination of domestic production and imports is an important tool to meet the objectives.

Learning from such situations, the Commission in 2006 produced a Green Paper, European strategy for sustainable, competitive and secure energy, to reaffirm the character of Europe's energy

9 Official Journal of the European Communities. (2001). Directive 2001/77/EC on the promotion of electricity produced from renewable energy resource in the internal electricity market. [online].http://eur-lex.europa.eu/legalcontent/EN/TXT/PDF/?uri=CELEX:32001L0077\&from=EN

10 Official Journal of the European Union. (2003). Directive 2003/30/EC on the promotion of the use of biofuels or other renewable fuels in transportation sector. [online] http://ec.europa.eu/energy/res/legislation/doc/biofuels/en_final.pdf .

11 Based on the European Wind Energy Association (EWEA) analysis, which was the topic of a press release on 12 January 2012, the EU achieved its 21 per cent renewable energy electricity of total electricity consumption. [online] http://pr.euractiv.com/pr/info-eu-met-its-2010-renewable-electricity-target-ambitious-2030-target-needed-91929 .

12 Commission of the European Union. (2007). Biofuel progress report. [online] http://eur-lex.europa.eu/legalcontent/EN/TXT/PDF/?uri=CELEX:52006DC0845\&from=EN.

13 Commission of the European Union. (2005). Biomass action plan. [online] http://ec.europa.eu/energy/res/biomass_action_plan/doc/2005_12_07_comm_biomass_action_plan_en.pdf.

14 Commission of the European Union. (2006). An EU strategy for biofuels. [online] $\mathrm{http}$ //ec.europa.eu/energy/res/biomass_action_plan/doc/2006_02_08_comm_eu_strategy_en.pdf. 
policies. The Commission emphasised that it should serve the objectives of sustainability, competitiveness and security of supply. ${ }^{15}$ The strategy also set some indicators for a future common European energy policy. This Green Paper attracted extensive responses that gave support for a common energy policy with a strong emphasis on sustainability over security of supply and competitiveness. ${ }^{16}$

On 10 January 2007, the EU proclaimed a renewable energy roadmap, which introduced three features: a new 20 per cent goal for renewable energy shares, a 20 per cent reduction in $\mathrm{CO}_{2}$ emissions by 2020 , and a minimum target of 10 per cent use of biofuels in the transport sector and recognition of a new legislative format for promoting renewable energy. In addition, this roadmap put the heating and cooling sector, together with the transport and electricity sectors, as the preferred sectors for renewable energy. ${ }^{17}$ The roadmap was soon manifested as a proposal for legislation by the Commission on 23 January 2008. Co-decision-making procedures by the EP pushed for amendments to the proposal. Comparing the Commission's renewable energy roadmap, it appeared that the EP had redefined the 10 per cent figure in transport sector to be not exclusively for biofuel but for general renewable energy sources. In addition, the EP also raised the importance of social sustainability together with environmental sustainability in proposing amendments. ${ }^{18}$ The Commission by the end of 2008 accepted the amendments from the EP at the first reading. On 6 April 2009, the Council also agreed with the EP position.

The EU Renewable Energy Directive (RED) was issued on 23 April 2009. The RED amended the previous directives 2001/77/EC and 2003/30/EC. There are three important features of the RED. First, its directive status is binding and mandatory for EU-MS. As such, EU-MS have to transpose the RED into their national legislation to set up schemes for promoting the use of renewable energy in the country. Unfortunately, the RED does not specify clear sanctions for those members that fail to meet objectives. Nevertheless, the Commission, under the infringement procedure, might send non-compliant countries to the EU Court of Justice, which can impose a periodic penalty and lump sum payment.

Second is the specific set of sustainability criteria for the biofuels and bioliquids allowed to be counted to meet the quota. These criteria are listed in article 17 (2) on $\mathrm{CO}_{2}$ emission reduction, which set a minimum of 35 per cent until 2017. The greenhouse gas (GHG) reduction target will increase to 50 per cent after 2017. However, for refineries that begin operating from 2017, 60 per cent will be required. Furthermore, in article 17 (3) it is stated that biofuels and bioliquids should not be obtained from areas of high biodiversity value, such as forest undisturbed by significant human activity, areas legally designated for nature protection and highly biodiverse grassland. All these areas should have had their status confirmed in or after January 2008. In addition, article 17 (4) also added that biofuels and bioliquids should not be produced from high carbon stock areas. Those areas are wetlands, continuously forested land and land spanning more than one hectare with trees higher than five metres and canopy cover between 10 and 30 per cent. Peatland is also forbidden to be exploited under article 17 (5).

15 Commission of the European Community. (2006). Green Paper. European strategy for sustainable, competitive and secure energy. [online] http://europa.eu/documents/comm/green_papers/pdf/com2006_105_en.pdf .

16 Commission of the European Community. (2006). Commission staff working document. Summary report on the analysis of the debate on the Green Paper, a european strategy for sustainable, competitiveness and secure energy. [online]. http://ec.europa.eu/energy/strategies/consultations/doc/2009_09_24/2006_11_16_sec_1500.pdf

17 Commission of the European Communities. (2007). Renewable energy roadmap. Renewable energies in the 21st century: building more sustainable future. [online] http://eur-lex.europa.eu/legalcontent/EN/TXT/PDF/?uri=CELEX:52006DC0848\&from=EN.

18 European Parliament. (2008). Draft European Parliament Legislative Resolution. [online] http://www.europarl.europa.eu/sides/getDoc.do?type=REPORT\&reference=A6-2008-0369\&language=EN . 
Third is the mechanism for verification of the RED sustainability criteria. It can be acquired through bilateral agreement, direct compliance with EU-MS certification and compliance with 19 acknowledged certification methods established by the Commission. The bilateral agreement mechanism is not applicable by the EU since the enactment. ${ }^{19}$ However, recently, the Indonesian government proposed a common trade platform for palm oil through a voluntary partnership agreement under the Vegetable Oil Sustainability Enforcement Government and Trade scheme. ${ }^{20}$ This proposal is at an infant stage because it was circulated during the meeting of Indonesia-EU working group on trade and investment. It has not yet been discussed formally with the Commission.

\section{THE ROLE OF NGOS AND THIRD NATION COUNTRIES (INDONESIA) IN THE RED FORMATION}

The controversial element of the RED is the set of criteria for sustainability that accompanies the EU commitment to increase the proportion of energy from renewable sources. The criteria had been twice up for discussion in public consultations held by the Commission. Based on the EU legislation process, public consultation is necessary for the Commission to consider the many inputs from many interested parties before drafting a legislative proposal. The public consultation might not directly influence the EU legislation bodies in their decision-making but it ensures transparency of process. However, public consultation is important for non-state actors, such as NGOs, as well as third national countries, enabling them to raise their concerns on the proposed legislation.

The first public consultation was held from 16 May to 18 June 2007. This public consultation raised several issues related to biofuel sustainability systems, land-use monitoring, and secondgeneration biofuel development. Table 1 shows some of the opinions of stakeholders.

Table1. NGO and third nation country perspectives on the Commission's public consultation on biofuel issues for new legislation on the promotion of renewable energy, 16 May18 June $2007^{21}$

\begin{tabular}{|c|c|c|c|}
\hline Actor & Biofuel sustainability system & Land-use monitoring & $\begin{array}{l}\text { Development of } 2 \mathrm{nd} \\
\text { generation biofuels }\end{array}$ \\
\hline $\begin{array}{l}\text { World Wide } \\
\text { Fund for Nature } \\
\text { (WWF) }\end{array}$ & $\begin{array}{l}\text { The European bioenergy should } \\
\text { analyse the use of recognised } \\
\text { sustainability standards before using } \\
\text { a new sustainability scheme (meta- } \\
\text { standard system). }\end{array}$ & $\begin{array}{l}\text { Recognising the indirect } \\
\text { land-use change and } \\
\text { should be monitored. }\end{array}$ & $\begin{array}{l}\text { Second generation will only be } \\
\text { favoured if it delivers on GHG. }\end{array}$ \\
\hline Greenpeace & $\begin{array}{l}\text { Greenpeace does not believe the } \\
\text { current certification, such as RSPO, } \\
\text { could deliver sustainable biofuels. } \\
\text { This institution defined sustainable } \\
\text { biofuels as fuels produced in } \\
\text { sustainable ways and efficiently } \\
\text { used. Other than indicators, such as } \\
\text { GHG emission, carbon stock and } \\
\text { biodiversity preservation. } \\
\text { Greenpeace added that biofuels } \\
\text { production must not release } \\
\text { genetically modified organisms. }\end{array}$ & $\begin{array}{l}\text { Active monitoring } \\
\text { through biennial } \\
\text { assessment should } \\
\text { include options for } \\
\text { suspension and } \\
\text { postponing of biofuel } \\
\text { targets. }\end{array}$ & $\begin{array}{l}\text { Only lingo cellulosic and } \\
\text { waste-based biofuels should be } \\
\text { considered as } 2 \text { nd generation } \\
\text { biofuels. However, it should } \\
\text { comply with similar } \\
\text { sustainability criteria as for } 1 \text { st } \\
\text { generation. }\end{array}$ \\
\hline
\end{tabular}

19 Interview with Rutha Balthause, representative of EU DG energy in charge in international cooperation and social sustainability in 2012 .

20 Yulisman, Linda. (2014). RI proposes trade platform for CPO exports. [online] http://www.thejakartapost.com/news/2014/03/21/ri-proposes-trade-platform-cpo-exports.html

$21 \mathrm{http}: / /$ ec.europa.eu/energy/renewables/consultations/2007_06_18_biofuels_en.htm. 


\begin{tabular}{|l|l|l|l|}
\hline Sahabat Alam & $\begin{array}{l}\text { First, it should address the social } \\
\text { implication of biocrops in producing } \\
\text { countries. Equally recognising } \\
\text { socially harmful systems as } \\
\text { environmentally harmful, such as the } \\
\text { customary rights of indigenous } \\
\text { peoples on ancestral domains. It } \\
\text { should also recognise competition } \\
\text { between land for food production } \\
\text { and land for energy. }\end{array}$ & $\begin{array}{l}\text { Multi-stakeholder } \\
\text { approach involving } \\
\text { exporting and importing } \\
\text { countries that allowed for } \\
\text { inputs and objections } \\
\text { accepted and recognised } \\
\text { through a continuous and } \\
\text { transparent process. }\end{array}$ & $\begin{array}{l}\text { Agricultural residues are } \\
\text { desirable. }\end{array}$ \\
\hline $\begin{array}{l}\text { Malaysian } \\
\text { Government }\end{array}$ & $\begin{array}{l}\text { Sustainability should be designed } \\
\text { according to the laws and } \\
\text { regulations of the exporting country. }\end{array}$ & $\begin{array}{l}\text { It should be left to the } \\
\text { laws and regulation of } \\
\text { the individual country. }\end{array}$ & $\begin{array}{l}\text { Biofuel from cellulosic material } \\
\text { should be developed that is } \\
\text { commercially viable and } \\
\text { scientifically proven. }\end{array}$ \\
\hline
\end{tabular}

As shown in Table 1, various points of view emerged from the Commission's consultations. In relation to the biofuel sustainability system, international NGOs, such as the World Wide Fund for Nature (WWF) and Greenpeace, and a local NGO, Sahabat Alam, have different opinions. The WWF confidently proposed a meta-standard system to the EU. In this system, the EU would build a set of sustainability criteria as the meta-standard. However, in the compliance process, the EU should also recognise other established sustainability criteria that are in accord with the meta-standard. ${ }^{22}$

Quite opposite to the WWF opinions, Greenpeace clearly rejected current established sustainability criteria. Greenpeace believes that there is no system that guarantees sustainable biofuel production because of the implications of the lack of regulation of indirect land-use change and rising food prices. Greenpeace insists on active and dynamic monitoring of GHG emissions, of major carbon stock and high biodiversity areas and also of genetically modified organisms released to the environment. Any breach of those indicators should provide enough reason for the EU to review the standards.

The view from international NGOs (Greenpeace and the WWF) is different from the local (Indonesian) NGO's perspective. Sahabat Alam highlighted the importance of the social implications of developing biocrops. This NGO argues that the proposed sustainability criteria too heavily emphasise environmental sustainability. It is not adequate to capture the legal and social conditions in a producing country, such as Malaysia. Similar concerns are shared by Sawit Watch and Oxfam Novib in Indonesia, which have raised the importance of the social implications of biofuel development, such as social conflict and food security. ${ }^{23}$

Strong opposition to the EU proposal comes from the Malaysian government, which insists that sustainability matters should be left to national authorities. Opinion from other potential biofuel countries, such as Indonesia, are not listed in this public consultation.

The second public consultation was held from 16 July to 30 September 2008. This consultation is related to the sustainability scheme for energy uses of biomass. In this consultation, only the Indonesian government's submission is available in the published public account of the consultations. Other views of representatives from NGOs and third nation countries in the previous public consultation are not available. In spite of this, several questions brought to the Commission attention were related to sustainability systems.

22 Lin, Jolene. (2010). The sustainability of biofuels: limit of the meta-standard approach. The Governance of Clean $\begin{array}{lllll}\text { Development } & \text { Working } & \text { Paper } & \text { Series } & 011 .\end{array}$ .http://www.tyndall.ac.uk/sites/default/files/GCD_WorkingPaper011.pdf .

23 Interview with Sawit Watch and Oxfam Novib Indonesia in 2012. 
There are two Indonesian government bodies involved in the public debate: the Indonesian Palm Oil Board (Gembungan Pengusaha Kelapa Sawit Indonesia [GAPKI]) and the Indonesian Department of Forestry. Table 2 paraphrases both institutions' submissions regarding the EU's sustainability scheme, GHG emission targets, issues related to land-use efficiency, sustainable forest management and verification.

Table 2. Indonesian Palm Oil Board and the Forestry Department on the Commission's public consultation on sustainability scheme for energy uses of biomass, 16 June-30 September $2008^{24}$

\begin{tabular}{|l|l|l|}
\hline & Indonesian Palm Oil Board & $\begin{array}{l}\text { Secretary of Directorate General Land } \\
\text { Rehabilitation and Social Forestry, } \\
\text { Indonesian Department of Forestry }\end{array}$ \\
\hline Sustainability schemes & Voluntary scheme & Legally binding \\
\hline GHG target & Lower than 35 per cent. & $\begin{array}{l}\text { The transport and heating sectors have } \\
\text { similar GHG emission targets. }\end{array}$ \\
\hline Land-use issues & $\begin{array}{l}\text { Several terms, such as 'forest } \\
\text { undisturbed', 'high biodiversity grassland' } \\
\text { and 'wetland conversion' do not } \\
\text { correspond with conditions in Indonesia. }\end{array}$ & $\begin{array}{l}\text { Biofuel and bioliquids should be produced } \\
\text { from land or areas that are not functioning } \\
\text { as forest, protected forest or areas of high } \\
\text { biodiversity. Therefore, there is no } \\
\text { problem with the proposed definition. }\end{array}$ \\
\hline $\begin{array}{l}\text { End use efficiency } \\
\text { management }\end{array}$ & $\begin{array}{l}\text { Bonuses should be granted in a national support scheme. } \\
\text { sustainable forestry for energy purposes. }\end{array}$ & $\begin{array}{l}\text { Sustainable forest management of forest } \\
\text { biomass for energy purposes should be } \\
\text { developed. }\end{array}$ \\
\hline Verification & ISO19011 forest & \begin{tabular}{l} 
Necessary \\
\hline
\end{tabular}
\end{tabular}

Compliance with the RED emphasised the important principle of traceability in which sustainability should be ensured in each biofuel production chain. In this context, these two Indonesian government bodies are the agencies most concerned with policies related to palm oil production. The Indonesian Palm Oil Board (IPOB) under the Directorate General of Plantations, Ministry of Agriculture, is the body that has authority in the production of palm oil. Its fellow agency, the Ministry of Forestry, is the ministry responsible for approving areas for plantations through the land-use change policy.

It is interesting to observe that both institutions have different perspectives on the formation of the EU RED, although both represent Indonesia at the EU public consultations. In terms of sustainability schemes for instance, IPOB is in favour of voluntary mechanisms rather than legally binding. In this way, the power to determine sustainability of biomass or biofuel is in the hands of producers and providers. A voluntary system gives a wider sense of acknowledgment to the dynamics of production mostly in developing countries. Therefore, it is not surprising when IPOB stresses the importance of definitions, such as for 'forest undisturbed', 'high biodiversity grassland' and 'wetland'. Singular and too rigid a definition of areas eligible for sustainability in biofuel production might be counter-productive to the goals of the institution. The Indonesian Palm Oil Board has to advance its interests in increasing palm oil production to supply the demand by opening new areas for plantations. It means this institution requires more land for new plantations.

This is contrary to the intentions of the Ministry of Forestry to preserve land, in this case Indonesian forest, in relation to Indonesia's commitment to reducing GHG emissions. This

24 http://ec.europa.eu/energy/renewables/consultations/2008_09_30_biomass_en.htm 
framework, legally binding sustainability criteria, welcomes a higher GHG emission target and additional forest management for forest biomass by the EU by the institution.

\section{THE DYNAMICS OF EVENTS IN CONSTRUCTING A PALM OIL IMAGE IN THE POST- RED ADOPTION ERA}

\section{The Lisbon Treaty And Sans Huile De Palms}

The mandated targets in the RED and the emphasis of the Commission in setting imported biofuel and biomass quotas have raised concerns from environmental NGOs. This concern has been voiced through the formal structure of EU decision-making as shown by the public consultations in 2006 and 2007. The environmental NGOs, such as Greenpeace, worry that the biofuel demand that has been encouraged will induce producers in third nation countries, such as Indonesia, to expand their plantations to meet the demands of the new market. In addition, these NGOs also touched on the indirect issues related to the conversion of agricultural land for biofuel crops. This might cause increases in food prices.

Another path these NGOs have taken to voice their concerns is to work outside the formal structure of the EU. Rather than aiming at powerful organisations, such the EU, which is unlikely to listen to their opinions, Greenpeace directed its efforts at multinational companies that share similar needs for raw materials for production. In April 2008, a feature article was published in the Greenpeace website about Unilever, the biggest palm oil consumer and member of Roundtable for Sustainable Palm oil (RSPO) Unilever buys palm oil from companies that destroy rainforests and peatlands, and whose activities endanger the habitat of the orang-utan. ${ }^{25}$ One month after this article was published, Unilever launched the 'Unilever palm oil video', which stated that by 2015 the company will use palm oil produced by sustainable methods only. ${ }^{26}$ These actions by both institutions were a month from the second public consultation before the RED was adopted. ${ }^{27}$

The implementation of the Lisbon Treaty, which was signed in 2007 and came into force in 2009, increases interaction between non-state and state agencies and the supranational EU. This treaty provides formal places for greater representation and involvement of European citizens (EZ), of EU-MS national parliaments as well as EU-MS representation in EU supranational governance. It enables active and formal political interaction in decision-making among these agencies.

Take, for instance, the EU Citizen Initiative (ECI). This is a mechanism for inviting a proposal from a European citizen for legislation by the EC. It covers a wide range of matters where the EC has the power to legislate: transport, agriculture and the environment. With the current 28 member states, this political accommodation enables more than 500 million people to have a direct influence on the supranational structures. As a consequence, tiny suggestions have the possibility of becoming legitimate proposals and of changing political directions in the region. Indeed, this scheme should be expanded, it could also provide opportunities for civil society; businesses as well as nongovernment organisation that share similar interests, to support causes they have in common.

Similar to the ECI, the involvement of EU-MS national parliaments through a subsidiarity principle could play a role in the supranational governance. With this principle, national parliaments

25 Greenpeace. (2008). Unilever 'monkey business': Greenpeace swing into action. [online] http://www.greenpeace.org/usa/en/news-and-blogs/news/unilever-s-monkey-business/ .

26 Unilever. (2008). Unilever Palm Oil Video. [online] http://www.unilever.com/sustainable-living-2014/news-andresources/sustainable-living-news/unileverpalmoilvideo.aspx.

27 Although it is hard to justify that the actions of both institutions directly influenced the adoption of the RED. However, the fact that RSPO had to create RSPO-RED to comply with EU sustainability criteria shows its effect. Potter mentioned that acknowledging the point of vulnerability of powerful organisation is one of the determining factors of successful NGO advocacy (Potter, 1996) 
are eligible to consider whether Commission proposals would be appropriate for and achieve better results at EU supranational governance level or at a shared EU-MS level. Along with the principle, there are several areas of responsibility that should be shared between the supranational and the national governments; for example, energy, environment and public health. In another words, transferring powers of the Union to the community in decision-making also opens opportunities for the EU-MS and non-state actors to challenge EU policies.

In 2011, a French senator, Yves Daudigny, proposed a 'Nutella tax' on palm oil. The senator argued that palm oil is harmful to the environment and that consuming palm oil can cause health problems. ${ }^{28}$ Although the French parliament rejected the proposal, Senator Doudigny's initial strategy took advantage of an opportunity created by EU regulation 1169/2011 on food labelling and palm oil after the implementation of the RED. As a result, the senator's initiative was followed by the adoption of 'sans huile de palm (no palm oil)' labelling by major food producers and retailers; for example, Casino and Carrefour. In 2014, Doudigny, together with his compatriot Catherine Doroche, once again proposed a 'behavioural tax' for palm oil, which is to be debated in the French parliament by the end of the year. ${ }^{29}$ Similar action is reported from other EU-MS; Belgium and the Ukraine. ${ }^{30,31}$

In this case, implementation of EU regulations on food labelling has been challenged by EUMS. The regulation, which is to protect EU citizens' health by giving full information on food ingredients and on nutrition, has been synchronised with taxation measure. This tax measure is necessary to ensure compliance by food producers. At the same time, the tax could discourage consumption of particular ingredients that are considered harmful to health. This EU-MS interpretation of the legislation is displaying one purpose of the regulation, which is to amend directives 2000/13/EC (on foodstuffs labelling, presentation and advertising) and 90/496/EEC (on food nutrition labelling).

\section{EU anti-dumping charges on Indonesian palm oil}

The implementation of the exclusive sustainability criteria of the RED does not necessarily mean exclusion from the European market of unsustainable biofuels, bioliquids and raw materials to produce those fuels. Close study leads one to believe that the RED is a form of trade barrier. This is partly true because implementing the RED has caused trade disruption. The palm oil exporting countries have to adjust their commodity to meet the requirements of the new market in sustainable biofuels. However, it might be a mistake because, in the context of its implementation, the RED hardly discriminates against other types of biofuel. Biofuels or biomass or both, that fail to comply with the RED are still allowed to enter the market. However, this type of biofuel will not be accounted for in meeting the RED target. In addition, the RED has also permitted a mass-balance system in determining what sustainable biofuels are to be included. With this method, sustainable biofuels can be blended with so-called unsustainable biofuels. However, around 10 per cent only of the total blending is accountable in the RED sustainability system. In other words, through the RED, the EU tries to convince its trading partners to realise and understand that the region's political dynamics have caused a demand for more a sustainable orientation and schemes for international trading.

28 Asia Palm Oil Magazine. (2013). 'French Senate passes Nutella tax', 1(4). [online] http://www.asiapalmoilmag.com/PALMAG\%20Jan-Mar\%202013.pdf .

29 Hanim, Adnan. (2014). Another palm oil drive. [online] http://www.thestar.com.my/Business/BusinessNews/2014/06/07/Another-antipalm-oil-drive-French-politicians-calling-for-new-taxes-on-food-and-beveragesdeemed-dan/?style=biz.

$30 \mathrm{http}: / / w w w . e u r o p a r l . e u r o p a . e u /$ sides/getAllAnswers.do?reference=E-2013-008455\&language=EN

31 http://www.kyivpost.com/content/ukraine/mp-baloha-proposes-banning-palm-oil-in-food-production-321695.html. 
Unfortunately, the enforcement of regulation 1194/2013, which applies anti-dumping duties to Indonesian biodiesel, shows the EU's double standards for third nation countries. The EU argues that the Indonesian government's policies to apply a differential export tax (DET) over the period 2010 to 2012 enabled the country to set lower biodiesel prices compared to EU domestic production. The Secretary-General of the European Biodiesel Board, Rafaello Garafallo, stated that the DET let Indonesia set a price for palm oil 35 to 40 per cent lower than the world market price. He further asserted that the DET would kill the European biodiesel industry faster than the EU legislation on indirect land-use change (ILUC). ${ }^{32}$

Theoretically, the enactment of a DET in producer country can induce a commodity price increase on the international market. However, there are some reasons for the implementation of a DET that should be considered before stating that it is an unfair international trade practice. There are some arguments in favour of a DET: terms of trade arguments, stabilisation of domestic prices, export earnings and income, controlling inflation pressures, infant industry arguments and retaliation to tariff escalation in export markets, easing government revenue collection and helping the poor. ${ }^{33}$ With the current Indonesian administration, without discounting other reasons, the argument is for building infant industries by implementing a DET. The export structure of Indonesian palm oil, which has been dominated by crude palm oil (CPO) rather than refined palm oil, has caused the government to strengthen downstream palm oil industries. The implementation of a DET is one of the incentives to push local industry to produce derivative products of palm oil, such as biofuels.

Similar to environmental issues, DET is a contentious subject in international trade circles. It is not necessarily related to direct technical production processes of the commodities but it is one of those factors that does affect commodity prices. Therefore, with this in mind, the EU supposedly considers it the motive behind the DET implementation. However, rather than establish bilateral communications about the matter, the EU, through the Commission, preferred to conduct a partial investigation before imposing the anti-dumping tax. The EU has been comfortable to settle the antidumping case through WTO mechanisms.

\section{PLACING THE PALM OIL ISSUES IN THE INDONESIA-EU TRADE RELATIONS}

The EU transition to a green economy not only has initiated regional industries, such as biofuel, to boost production but it has also opened opportunities for third nation countries to supply the market. After the implementation of EU directives to boost the use of renewable energy in the transport, electricity and heating sectors, the market share of palm oil in the EU notably increased. Of the three sectors, the transport sector consumes palm oil the most. ${ }^{34}$ Indonesian palm oil enjoyed a rising market share trend from 26 to 35 per cent over the period from 2005 to 2010 . In the following years, the trend has declined. In 2013, Indonesian palm oil had a 29 per cent share of the EU market. This market share is higher than Malaysia's, which has also suffered a decline since 2010. Malaysia's share fell from 23 per cent in 2011 to 16 per cent in 2013.

32 Euractiv. (2013). Indonesian palm oil faces EU bar over tax loophole. [online] http://www.euractiv.com/developmentpolicy/indonesian-palm-oil-faces-eu-bar-news-529579 .

33 Piermartini, Roberta and ERSD. (2004). The role of export taxes in field of primary commodities. Geneva: World Trade Organization. pp. 7-15.

34 Study result from GSI and IISD shows that in the period 2006 to 2012, the end use of palm oil in the European market has been dominated by biodiesel production. This sector alone enjoyed a 365 per cent change or increase from 402,000 metric tonnes to 1869,000 metric tonnes in 2012. Electricity and heat generation arre placed second with a 40 per cent change. Meanwhile food, personal care and other oleo-chemical products listed a 6 per cent increase. (Geramsimchuk, Ivetta and Peng Yam Koh. (2013). The EU biofuel policy and palm oil: cutting subsidies or cutting rainforest. The International institute for Sustainable Development.) 
The EU market could be said to have a different type of palm oil customer. Unlike India and China, which are, respectively, the first and third biggest markets for Indonesian palm oil, the EU's sustainability requirements for the palm oil production make it a picky customer. Indeed, as the current biggest palm oil producer in the world, Indonesia serves all markets. Several measures have been taken to overcome these market challenges. The first, started in 2011, is the implementation of Indonesian Sustainable Palm Oil (ISPO), which is a national certification standard. ISPO is to ensure sustainability practices in palm oil production for companies and smallholder farmers, although a specific ISPO for the latter set of producers is still being developed. Forty palm oil companies operating in Indonesia at present produce two million tons of certified sustainable palm oil. ${ }^{35}$ These companies account for at least 10 per cent of Indonesia's palm oil exports. Even though the tonnage is still relatively small compared to sustainable palm oil under the RSPO mechanism, which produces around ten million tons, ISPO shows the government's commitment to take sustainable palm oil to markets elsewhere in the world.

It cannot be denied that palm oil development in Indonesia has detrimental effects on social wellbeing and the environment. These effects have been given a deal of publicity that has tarnished the image of palm oil. Figure 1 shows the relation between the negative images of Indonesian palm oil in the EU market and how these have affected export volumes.

\section{Figure 1. Indonesian palm oil exports to the EU}

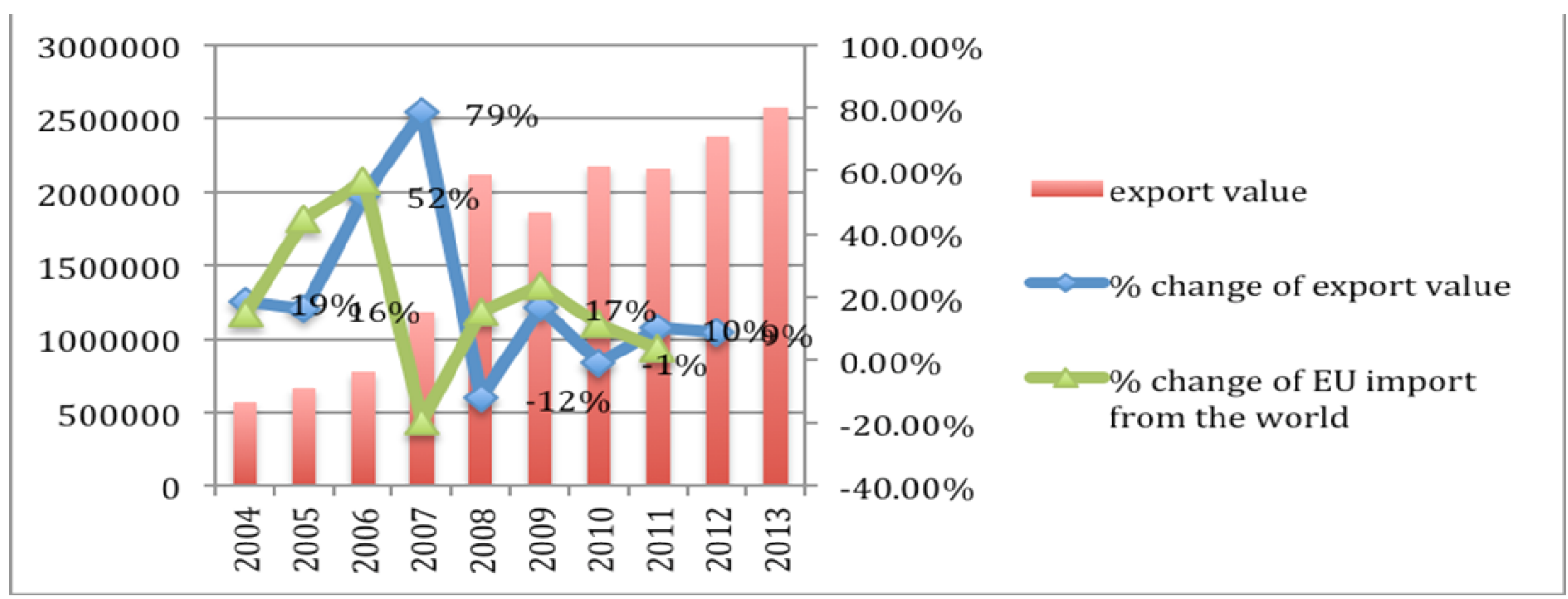

Source: UN Comtrade

In terms of export value, the tendency has been to increase year after year. In addition, the congruency of the percentage annual change of export value with EU palm oil imports from the world shows Indonesian domination in the EU market. However, the annual export value percentage clearly depicts the relation of EU political dynamics with palm oil market sensitivity in the region. It shows that the highest annual change was recorded in 2008, almost a doubling of the increase in export value compare to the previous year. Since then, changes in palm oil export values have never been as high. It cannot be excluded that environmental NGOs' campaigns against palm oil highlighted it as a driver for biodiversity destruction. The social media strategies of these NGOs after 2008 were successful in catching public attention. The 'Kitkat video' was so influential because it was viewed 1.5 million times and initiated 200,000 e-mails of protest. ${ }^{36}$ Other initiatives, such as the 'Nutella tax', damaged the image of the commodity even more. These campaigns against palm oil

35 Amri, Qayyum. (2014). 'Sawit minyak nabati paling sustainable'. Sawit Indonesia, III(33).

36 The Economist. (2010). 'The campaign against palm oil: the other oil spill'. [online] http://www.economist.com/node/16423833. 
show that non-economic factors also play a role in explaining the decreasing volumes of Indonesian palm oil reaching the EU market.

With these examples in mind, measures to reconstruct palm oil's public image are important. One notable effort was made at the 2014 United Nations Climate Summit. The CEOs of Wilmar, Cargill, Asian Agri, Golden Agri-resource and the Indonesian Chamber of Commerce and Industry pledged their commitment to sustainability practices in the palm oil industry. The Summit was in New York, in a country that had expressed strong doubts about Indonesian commitment to reducing emissions. But the pledge, made on stage at the Climate Summit, in the presence of many representatives of environmental agencies, was a strategic move to change the public image of palm oil and to set this commitment in stone.

\section{CONCLUSION}

The formation of the RED did not come overnight: it took years. It involved many stakeholders, state and non-state in the EU and outside. In developing the RED, the stakeholders voiced their concerns and made their requests about the criteria for sustainability in the directive. Most of the nation states, including Indonesia, must take into account the technical feasibility of any standards set. The NGOs are concerned about the externalities of the criteria, such as ILUC, social conditions of the producing countries and food security. In addition, NGOs (read Greenpeace) are taking advantage of intersecting issues in palm oil. By directing attention and advocacy of environmental and energy matters to Unilever, which has a commercial interest in the commodity, Greenpeace successfully reoriented the company's commitment to sustainable palm oil.

Replicating his previous strategy, Yves Doudigny tried to utilise the intersecting issues of environment and health and to seize an opportunity created by the implementation EU regulations on food labelling. Although less successful than his previous campaign, it did induce a common purpose among other EU-MS to use a similar approach in selecting palm oil as an eligible commodity for further rules. The implementation of the Treaty of Lisbon, which acknowledges that community power, such as national parliaments and even individual citizens, may influence supranational decision-making, ensures that palm oil will always be the subject of attention. This is not an overstatement; palm oil has been utilised as a fuel, for heating and even in the food sector of the EU market. The EU anti-dumping tax is the new challenge for palm oil for the next five years.

In other words, the interactions of many issues that accompanied palm oil development over the past decade are the manifestations of the interests of many agencies. At some point, those different interests intersect and are channelled into EU secondary laws, such as directives or regulations. It is important to acknowledge that, once it is channelled, this does not mean the interaction is over. The RED, for example, is to accommodate the interests of environmental NGOs that are concerned about biodiversity destruction in Indonesia, the interests of European biodiesel producers in admitting new competitors, and the interests of the EU in building a secure and sustainable economy. Because RED has been implemented, the unfinished negotiation over the insertion of clauses dealing with indirect land-use change (ILUC) in the directive has caused a push for amendment. The dynamics of this have to be understood and anticipated by Indonesia; the biggest palm oil producer. Indonesia has to accept any negative action against palm oil as not simply a barrier to trade that invites retaliation policies in return, but also as an external incentive to restructure its palm oil industry. 


\section{REFERENCES}

Asia palm oil magazine. (2013). 'French senate passes Nutella tax'. Asia palm oil magazine, 1(4). [online] http://www.asiapalmoilmag.com/PALMAG\%20Jan-Mar\%202013.pdf

Amri, Qayyum. (2014). 'Sawit minyak nabati paling sustainable'. Sawit Indonesia, III(33).

Commission for the European Community. (1997). Energy for the future: renewable sources of energy. White Paper for a community and strategy and action plan. [online] http://europa.eu/documents/comm/white_papers/pdf/com97_599_en.pdf

Commission of the European Community. (1996). Energy for the future: renewable sources of energy. Green Paper for community strategy. [online] http://aei.pitt.edu/1280/1/renewalbe_energy_gp_COM_96_576.pdf

Commission of the European Community. (1993). Growth, competitiveness, employment: the challenges and ways forward into the 21st century. White Paper. [online] http://aei.pitt.edu/1139/1/growth_wp_COM_93_700_Parts_A_B.pdf

Commission of the European Communities. (2007). Renewable energy roadmap. Renewable energies in the 21st century: building a more sustainable future. [online] http://eurlex.europa.eu/legal-content/EN/TXT/PDF/?uri=CELEX:52006DC0848\&from=EN

Commission of the European Community. (2006). Commission staff working document. Summary report on the analysis of the debate on the Green Paper: a European strategy for sustainable, competitiveness and secure energy. [online] http://ec.europa.eu/energy/strategies/consultations/doc/2009_09_24/2006_11_16_sec_1500.p df

Commission of the European Community. (2006). Green Paper. European strategy for sustainable, competitive and secure energy. [online] http://europa.eu/documents/comm/green_papers/pdf/com2006_105_en.pdf

Commission of the European Union. (2006). An EU strategy for biofuels. [online] http://ec.europa.eu/energy/res/biomass_action_plan/doc/2006_02_08_comm_eu_strategy_en. pdf

Commission of the European Union. (2005). Biomass action plan. [online] http://ec.europa.eu/energy/res/biomass_action_plan/doc/2005_12_07_comm_biomass_action _plan_en.pdf

Commission of the European Union. (2007). Biofuel progress report [online] http://eurlex.europa.eu/legal-content/EN/TXT/PDF/?uri=CELEX:52006DC0845\&from=EN

European Commission. (2008). Public consultation: preparation of a report on requirements for a sustainability scheme for energy uses of biomass. [online] http://ec.europa.eu/energy/renewables/consultations/2008_09_30_biomass_en.htm

European Commission. (2007). Public consultation biofuel issues in the new legislation on the promotion of renewable energy. [online] http://ec.europa.eu/energy/renewables/consultations/2007_06_18_biofuels_en.htm

European Parliament. (2008). Draft European parliament legislative resolution. [online] http://www.europarl.europa.eu/sides/getDoc.do?type=REPORT\&reference=A6-2008$0369 \&$ language $=\mathrm{EN}$

European Commission. (2008). Public consultation: preparation of a report on requirements for a sustainability scheme for energy uses of biomass. [online] http://ec.europa.eu/energy/renewables/consultations/2008_09_30_biomass_en.htm 
European Commission. (2007). Public consultation: biofuel issues in the new legislation on the promotion of renewable energy. [online] http://ec.europa.eu/energy/renewables/consultations/2007_06_18_biofuels_en.htm

European Parliament. (2008). Draft European Parliament legislative resolution. [online] http://www.europarl.europa.eu/sides/getDoc.do?type=REPORT\&reference=A6-20080369 \&language $=\mathrm{EN}$

European Parliament. (2013). Parliamentary questions: answer given by Mr De Gucht on behalf of the Commission. [online] http://www.europarl.europa.eu/sides/getAllAnswers.do?reference=E-2013008455 \&language $=\mathrm{EN}$

Euractiv press release. (2012). Ru met its 2010 renewable electricity target--ambitious 2030 target needed. [online] http://pr.euractiv.com/pr/info-eu-met-its-2010-renewable-electricity-targetambitious-2030-target-needed-91929

Euractiv. (2013). Indonesian palm oil faces EU bar over tax loophole. [online] http://www.euractiv.com/development-policy/indonesian-palm-oil-faces-eu-bar-news-529579

Geramsimchuk, Ivetta and Peng Yam Koh. (2013). The EU biofuel policy and palm oil: cutting subsidies or cutting rainforest. The International institute for Sustainable Development

Greenpeace. (2008). Unilever 'monkey business', Greenpeace swing into action. [online] http://www.greenpeace.org/usa/en/news-and-blogs/news/unilever-s-monkey-business/

Hanim, Adnan. (2014). Another palm oil drive. [online] http://www.thestar.com.my/Business/Business-News/2014/06/07/Another-antipalm-oil-driveFrench-politicians-calling-for-new-taxes-on-food-and-beverages-deemed-dan/?style=biz

Kyivpost. (2013). MP Baloha proposes banning palm oil in food production. [online] http://www.kyivpost.com/content/ukraine/mp-baloha-proposes-banning-palm-oil-in-foodproduction-321695.html

Lin, Jolene. (2010). The sustainability of biofuels: limit of the meta-standard approach. The Governance of Clean Development Working Paper Series 011 [online] http://www.tyndall.ac.uk/sites/default/files/GCD_WorkingPaper011.pdf

Official Journal of the European Union. (2003). Directive 2003/30/EC of the promotion of the use of biofuels or other renewable fuels in transportation sector. [online] http://ec.europa.eu/energy/res/legislation/doc/biofuels/en_final.pdf

Official Journal of the European Communities. (2001). Directive 2001/77/EC on the promotion of electricity produced from renewable energy resource in the internal electricity market. [online] http://eur-lex.europa.eu/legalcontent/EN/TXT/PDF/?uri=CELEX:32001L0077\&from=EN

Piermartini, Roberta and ERSD. (2004). The role of export taxes in field of primary commodities. Geneva: World Trade Organization p: 7-15.

Potter, David. (1996). NGOs and environmental policies Asia Africa. London: Frank Cass.

The Economist, (2010). The campaign against palm oil: the other oil spill. [online] http://www.economist.com/node/16423833

Unilever. (2008). Unilever palm oil video. [online] http://www.unilever.com/sustainable-living2014/news-and-resources/sustainable-living-news/unileverpalmoilvideo.aspx

Yulisman, Linda. (2014). RI proposes trade platform for CPO exports. [online] http://www.thejakartapost.com/news/2014/03/21/ri-proposes-trade-platform-cpo-exports.html 